\title{
Estratégia\&Negócios
}

ISSN 1984-3372

http://www.portaldeperiodicos.unisul.br/index.php/EeN/

\section{ESTRATÉGIA DE VERTICALIZAÇÃO A JUSANTE: INGRESSO DE PRODUTORES NO VAREJO}

\section{STRATEGY VERTICALIZATION DOWNSTREAM: ENTRY OF PRODUCERS IN RETAIL}

\section{Roberto Minadeo}

Professor do Curso de Mestrado em Administração do Centro Universitário Euro Americano - UNIEURO.

E-mail: rminadeo@yahoo.com

Recebido em 07/06/2012. Aprovado em 20/08/2012. Disponibilizado em 01/10/2012. Avaliado pelo Sistema double blind review

R. eletr. estrat. neg., Florianópolis, v.5, n.2, p.56-87, mai./ago. 2012 http://portaldeperiodicos.unisul.br/index.php/EeN/index
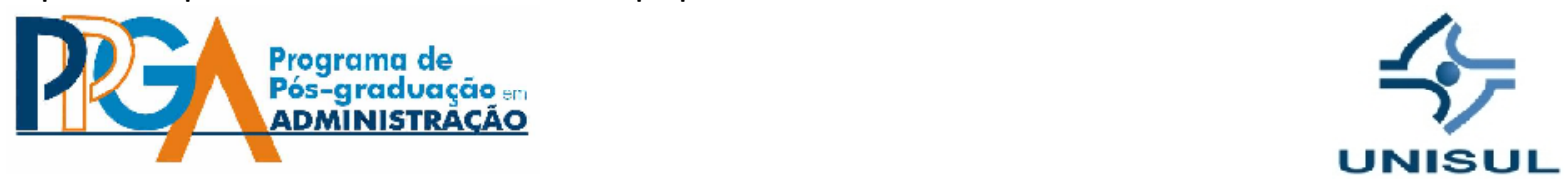

CCopyright 2008 UNISUL-PPGA/Estratégia e Negócios. Todos os direitos reservados. Permitida citação parcial, desde que identificada a fonte. Proibida a reprodução total. Em caso de dúvidas, consulte o editor: ademar.unisul@gmail.com; (48) 3229-1932. 


\section{RESUMO}

Ante o acirramento da concorrência, é cada vez mais vital a necessidade de se estabelecerem vantagens competitivas de modo a manter a empresa em atividade, com ofertas superiores aos consumidores em relação às dos concorrentes. O presente artigo apresenta e classifica algumas situações de verticalização de produtores de bens e serviços em direção ao varejo. O ingresso relativamente recente de vários grupos de grande porte em atividades varejistas não parece ser um modismo como vários outros movimentos empresariais que vieram a se mostrar efêmeros e mal compreendidos. A finalidade do artigo está em apresentar a produtores de bens e serviços algumas estratégias interessantes praticadas pelo mercado, de modo que se possa problematizar o eventual acerto ou até mesmo a possível adoção dessa estratégia. Outra finalidade do artigo está na própria apresentação de inúmeras situações - que mostram riqueza por parte de diversas companhias na forma de abordar o mercado e de buscarem o crescimento.

Palavras-Chave: Estratégia empresarial. Varejo. Estratégia de Verticalização.

\section{INTRODUÇÃO}

Em virtude de o novo quadro competitivo do setor varejista, algumas companhias do setor se viram na necessidade de apresentar inúmeras estratégias criativas e inovadoras. Por causa desse quadro específico do varejo, destaca-se o ingresso de companhias produtoras de bens ou prestadoras de serviços em atividades varejistas - nas quais anteriormente ainda não estavam presentes, com a finalidade de não mais dependerem apenas das tradicionais redes varejistas que adquiriam seus produtos visando à venda do produtor final.

O presente artigo foca especificamente o problema do ingresso de inúmeros fabricantes ou de prestadores de serviços no varejo - um fenômeno que tem 
sido marcante em importantes marcas, e que parece responder ao desafio dos grandes varejistas lançarem marcas próprias, o que poderia ser uma ameaça às marcas líderes. O objetivo deste estudo é fornecer possíveis insights criativos a companhias que estejam em situação de inferioridade em função do acirramento da concorrência além de apresentar uma descrição do setor, realizado com base em uma linha de pesquisa apoiada em história empresarial. Após esta introdução, a seção 2 traz o referencial teórico; a seção 3 aborda os procedimentos metodológicos que nortearam o estudo; a seção 4 apresenta os resultados; a seção 5 analisa e conclui os estudos, vindo ao final as Referências.

\section{REFERENCIAL TEÓRICO}

Em função da temática verticalização a jusante no varejo, o referencial teórico trata de: a) conceitos de verticalização; e b) situações de verticalização encontradas na literatura e que envolvem setores econômicos - ou seja, mais amplas do que as descritas neste estudo e que não são objeto, portanto, deste artigo. Esses assuntos foram abordados em função da classificação realizada em situações concretas de verticalização no sentido de ingresso de produtores no varejo, assim, tais temas foram vistos como necessários ao leitor para melhor compreender o que se segue.

\subsection{CONCEITOS SOBRE VERTICALIZAÇÃO}

A integração vertical ocorre quando entidades econômicas estão em níveis ou setores diversos, mantendo entre si relações comerciais, como o fornecimento da matéria-prima, a industrialização ou a venda de certa linha de produtos. Seu fim é a busca da independência tecnológica e a maximização dos lucros, mediante o controle da qualidade e dos custos da fabricação até seu destino final - na medida do possível. A verticalização pode ser de várias maneiras: a) pelo ingresso no mercado, 
concorrendo com seus antigos fornecedores de insumos; b) mediante uma aquisição de empresa, como um fabricante adquirindo uma rede varejista para escoar sua produção; e c) mediante contrato de exclusividade com fornecedores para obter os insumos de que necessita (KNIJNIK et al., 2002).

Segundo Lazzarini (2011), em 1931 e 1932, Ronald Coase, estudante britânico de 21 anos, mudou a Ford e a GM nos EUA, escrevendo "A Natureza da Firma", publicado em 1937, que Ihe daria o Prêmio Nobel em Ciências Econômicas, 54 anos mais tarde. Coase aponta que uma empresa pode se abastecer de componentes adquiridos no mercado, o que pode ser entendido como terceirização e focar no que veio a ser conhecido por core business. Porém, Coase percebeu muitas companhias saindo de seu negócio principal e atuando em áreas correlatas: a Ford participava de empresas de mineração, borracha, vidros, madeira e várias outras matérias-primas usadas em automóveis - algo exagerado nos padrões atuais. Porém, várias montadoras ainda produzem internamente alguns de seus componentes. Coase afirmou que as companhias deveriam internalizar uma atividade quando os custos de transação para executá-la no mercado de modo terceirizado fossem proibitivos.

Silva e Batalha (2001) afirmam que as vantagens da integração vertical estão ligadas à apropriação dos ganhos dos mercados a montante e a jusante da atividade original da empresa e/ou ao controle desses mercados para fortalecer essa atividade original. A integração a montante garante o fornecimento de matériasprimas. A integração a jusante aproxima a empresa dos consumidores, amplia sua diferenciação em qualidade e serviço ou controla melhor os canais de distribuição. Os autores acrescentam que os inconvenientes da integração são os investimentos - que podem ser eventualmente elevados, comprometendo a alocação de recursos na atividade principal. Também aumentam as dificuldades de gestão por essa multiplicidade de mercados de atuação. Finalmente, os riscos da empresa se multiplicam, pois qualquer problema na cadeia afeta todas as atividades da empresa; assim, ao invés de se aproveitar dos lucros de todos os mercados em que atua, podese incorrer em prejuízos pelo maior compromisso de recursos ao longo da cadeia produtiva. 
Entre 1895 e 1904, nos EUA, ocorreram 157 transações de porte relevante em Fusões e Aquisições (F\&A), excluídos os negócios do setor ferroviário. Essa onda teve um aspecto espontâneo: os grandes bancos de investimento atuaram em poucos negócios, sendo a maioria intermediada por corretoras de ações, bancos comerciais ou grupos especializados em F\&A. Chandler (1962) conclui que as empresas que continuaram independentes o fizeram ao alcançar importantes eficiências operacionais via verticalização; cerca de um terço das independentes veio a falir em um ano após importantes consolidações no setor (MORRIS, 2005).

Gurgel (2001) apresenta os seguintes argumentos a favor da verticalização: a) economia de escala: aproveitamento da capacidade ociosa; b) segurança: maior garantia de suprimento frente aos riscos de atrasos de fornecedores ou falhas de qualidade; e c) atividade: menor variação do nível de atividade produtivo, pois atuando em vários estágios, não será afetado em todos eles, ao haver uma redução temporária nas vendas. Porém, relata os seguintes pontos contrários à verticalização: a) necessidade de liberar capacidade de produção para usar em produtos mais rentáveis; b) custos: possibilidade de maior especialização e redução de custos ao adquirir itens de produtores que já atendem ao mercado; c) controle: redução do trabalho de gestão e dos estoques intermediários; e d) tecnologia: possibilidade de absorver tecnologia dos fornecedores externos, que poderá beneficiar o aperfeiçoamento dos processos internos.

\subsection{SITUAÇÕES DE VERTICALIZAÇÃO APONTADAS NA LITERATURA ENVOLVENDO SETORES ECONÔMICOS}

As grandes produtoras norte-americanas de petróleo ingressaram tardiamente na distribuição. Por volta de 1925 , vendiam apenas $20 \%$ de sua produção diretamente aos consumidores em seus próprios postos - cuja rede, no ano seguinte, somava 13.644 unidades. Em 1920, havia cerca de 42 mil garagens ou postos que vendiam gasolina. (BOWDEN, 1930). Em nosso país, a Agência Nacional do Petróleo, Gás Natural e Biocombustíveis (ANP) editou a Portaria 116, em julho/2000, que 
impede às distribuidoras de exercerem atividades varejistas - ou seja, de serem verticalizadas (NETO, 2009).

Segundo Tuon, Moisés e Minadeo (2011), o Brasil apresenta uma situação mundialmente inovadora no varejo, que se convencionou denominar "atacarejo". Mediante um estudo de campo, em nove lojas, comparando-se os preços de três hipermercados, três supermercados e três "atacarejos", estes últimos foram os que sistematicamente ofereceram os menores preços. Minadeo (2010) aduz que a aquisição do Atacadão pela filial brasileira do grupo Carrefour, em 2001, reconduziu o grupo francês à liderança do mercado brasileiro, e que um especial atrativo da operação realizada foi justamente o fato de a adquirida atuar no modelo "atacarejo" do qual foi dos grupos pioneiros, detendo 34 lojas. O autor acrescenta que em 2005, o Walmart adquiriu o grupo Sonae, do Sul do país, sendo um de seus ativos a bandeira Maxxi Atacado, igualmente um exemplo de atuação segundo o modelo do "atacarejo".

Ainda no sentido de agregar maior volume de serviços aos consumidores, o Carrefour foi a primeira grande rede do país a investir em postos independentes, ao comprar, em 2006, postos que operavam com as bandeiras Esso, Ipiranga e Repsol; chegando a uma rede de 79 postos. Além de vender combustíveis, oferecem outro atrativo: as lojas de conveniência - para o qual a rede lançou em 2007, o Carrefour Express. Em 2008, o Pão de Açúcar possuía postos de gasolina em 69 dos seus 91 hipermercados. Ao comprar os ativos do Sonae, em 2005, a Wal-Mart ficou com os três postos do grupo no interior de São Paulo, mas não expandiu a rede (MINADEO, 2008b).

Com a melhoria da logística e o aumento da produção, as empresas passaram a ter maior controle sobre seus insumos e a venda de seus produtos. A verticalização ensejou o surgimento das grandes empresas dos EUA (SONAGLIO; ZAMBERLAN, 2009). Giacomozzi, Labra e Caridi (2009) afirmam que são integrados verticalmente os grupos que possuem empresas relacionadas que complementam sua cadeia de valor, ou seja, detêm várias ou todas as atividades em um mesmo setor, pelo que seus negócios se complementam de modo a entregar um serviço mais eficiente e com menores custos. 
Casarotto Filho et al. (1998) apontam a estratégia de verticalização como interessante para pequenas empresas de elevado conteúdo tecnológico - pois é importante deter o conhecimento de todo o processo produtivo. Para Freitas (2003), a integração vertical é dominante na indústria de petróleo, pois permite reduzir as incertezas. Uma característica importante do setor: a demanda é inelástica, não reagindo a aumentos nos preços. Por outro lado, a má distribuição geopolítica da oferta leva a grandes esforços logísticos para garantir o suprimento. Tudo isso faz com que as grandes companhias do setor procurem adotar uma filosofia de verticalização, do poço ao posto.

Segundo Greiffo et al. (2006), existem 120 empresas no Espírito Santo no setor de rochas ornamentais. Em estudo que cobriu 51 delas, 16 do total de 26 das criadas após 1989 utilizam jazidas próprias. Das empresas fundadas até 1989, 15 das 25 não utiliza nem jazidas próprias nem de terceiros. Os autores afirmam existir diferença estatisticamente significativa neste caso, indicando divergência de estratégia: o uso de jazidas próprias implica maior autonomia e verticalização - o que não se verifica nas empresas antigas.

Situações interessantes de verticalização, que envolvem cooperativas, normalmente processadoras de commodities: a) a Cooperativa Aurora - após seu início de atividades como processadora de suínos - ingressou no setor de frango e leite, dado que o mercado de carcaças (animal inteiro congelado) praticamente não mais existe; a linha de produtos da Aurora soma 750 produtos, tendo $R \$ 3,8$ bilhões em receitas em 2011; b) a Coamo ingressou no varejo mediante vendas aos supermercados de médios e pequenos, fora das principais capitais do Sudeste, e suas receitas cresceram 62\% em 2011 em relação a 2010; além disso, suas linhas de margarina e óleo de soja estão entre as cinco mais vendidas do país; e c) a Itambé, cooperativa mineira focada em laticínios, foi ao varejo, começando pelo Nordeste disputando a liderança no setor de leite em pó (SCHELLER, 2012).

Em 2003, a gaúcha Todeschini decidiu distribuir seus móveis no Brasil apenas mediante lojas exclusivas. Outras empresas moveleiras de Bento Gonçalves seguiram esse rumo: Florense, Dell Anno, SCA, Manfrói, Bentec, Bontempo e Bertolini. 
Fabricantes de outros Estados que adotaram essa estratégia: Formaplas, Rudnick, Newman, Kitchen's e Millenium (FABIANO, 2005). A empresa Casas Bahia produz grande parte dos móveis que vende, possui frota própria para distribuir os produtos e conta com nada menos que novecentos profissionais de análises de crédito - dado que parcela em até 18 vezes aos seus compradores (ZANCUL, 2005).

Segundo Rodgers (1990), a IBM trabalhara apenas com sistemas de grande e médio porte, vendendo mediante equipe própria, até introduzir computadores pessoais - após o que passou a utilizar varejistas, ao lado de mala direta e catálogos. Teve que estruturar-se para apoiar esse novo canal de distribuição. Decidiu usá-lo porque os PCs chegam a milhões de pessoas, e o varejo é o melhor modo de alcançar esse público. Em 1984 havia dez mil pontos de varejo em todo o mundo trabalhando com a IBM. Mediante mala direta e catálogos, eram atendidos por volta de dez mil telefonemas por dia. A IBM precisou ingressar no canal varejista, pois sua experiência anterior era formada por vendas diretas junto a outras empresas, e, mediante esse novo canal, pôde comercializar o PC junto a um novo público formado por pessoas físicas.

Stross (2007) aponta que a principal inovação da rede de lojas Apple foi o "Genius Bar", com uma equipe de especialistas em diagnóstico, oferecendo serviços gratuitamente. Mais da metade do pessoal das lojas presta serviços de pós-venda tendo em conta que a maior parte dos clientes apresenta certa visão de que os PCs (aos quais já estão acostumados) são de uso mais fácil. Levy e Weitz (2000) afirmam que as lojas de Chicago da Sony e da Nike apresentam uma atmosfera que melhora a imagem da mercadoria, além de propiciar vendas. "As lojas NikeTown, o estúdio Warner Brother e as Disney Stores vendem Experiências temáticas com " $\mathrm{E}$ " maiúsculo." (KELLEY; LITTMAN, 2002, p. 233).

A Dell obteve sucesso com uma solução aos consumidores de PCs, superando o trauma de lidar com artigos técnicos mediante a compra direta - o que fez a compra tão fácil quanto a de um lanche (KELLEY; LITTMAN, 2002). Porém, Rosa e Facchini (2007) afirmam que a partir de Maio de 2007, a Dell abandonou sua 
tradicional política de distribuição exclusiva mediante vendas diretas, começando a utilizar varejistas (MICROSOFT..., 2009).

\section{ASPECTOS METODOLÓGICOS}

A pesquisa é exploratória, em função da carência de informações sobre verticalização de fabricantes rumo ao varejo. A forma de apresentação dos dados é descritiva - pois não teve caráter explicativo nem analítico, visando contextualizar e classificar diversos processos de ingresso de fabricantes e/ou produtores de serviços no varejo. Não se pretendeu esgotar as possíveis categorias existentes para classificar as situações encontradas de verticalização. Além disso, em função do espaço, apenas alguns processos foram analisados - sem serem emitidos juízos de valor no sentido de comparar processos de verticalização ou de se procurar emitir juízos de valor em relação à própria estratégia subjacente a cada operação. Finalmente, o escopo do artigo é exploratório em função de terem sido encontradas poucas pesquisas acadêmicas sobre verticalização enquanto estratégia de negócios, e, por isso, o texto pretende subsidiar posteriores desdobramentos.

O ponto de partida de uma investigação científica deve basear-se em um levantamento de dados. Para isso, requer-se uma pesquisa bibliográfica. Em um segundo momento, realiza-se uma observação dos fatos para obter maiores informações, e, em um terceiro momento, se faz contato com pessoas que possam fornecer dados ou sugerir possíveis fontes de informações (BONI; QUARESMA, 2005). Neste artigo, o foco está nas duas primeiras etapas apontadas pelos autores - pela impossibilidade de se ir a campo, diante de uma tão grande amplidão de dados obtidos. Dados secundários, segundo Révillion (2001) são coletados para fins diversos do problema de pesquisa específico; na maioria das vezes, são informações de obtenção mais rápida, acessível e barata do que os dados primários. 
A pesquisa também foi histórica - suprida por uma Linha de Pesquisa ativa há vários anos no tema da História Empresarial. Não houve uma preocupação de se realizar cortes temporais no estudo, porém, apenas se procurou escolher situações de verticalização de produtores ou prestadores de serviços em direção ao varejo. Lakatos e Marconi (1991) apontam que o método histórico pressupõe que as instituições se originam no passado, sendo importante pesquisar suas raízes, visando compreender sua natureza e função. Investigam acontecimentos, processos e instituições passadas para verificar a sua influência no presente. Segundo Sauerbroon e Faria (2009), caberia ampliar a rede de estudos para melhor compreensão dos problemas mercadológicos. Os autores apontam a necessidade de se retornar ao uso do método histórico, em pesquisas mercadológicas, visando trazer o próprio contexto das organizações para o centro dos estudos - desde a formulação do problema de pesquisa, até o desenvolvimento das conclusões.

Quanto ao enfoque, a pesquisa é qualitativa. Conforme Hair et al. (2005) e Mattar (2005), pesquisa qualitativa é aquela em que se busca a presença ou ausência de um fenômeno e utiliza dados qualitativos. Sendo assim, a classificação dos dados nos diversos quadros foi essencialmente qualitativa, com enfoque nos aspectos motivacionais de cada situação.

A Linha de Pesquisa acima apontada trouxe como fontes de informação: a) dissertações, artigos e livros acadêmicos, de negócios e de históricos empresariais, no tocante ao tema dos canais de distribuição em geral e do varejo em particular, além de estudos de casos; e b) imprensa especializada: b1) impressa: Folha de São Paulo, 0 Estado de São Paulo, Época Negócios; b2) online: Meio \& Mensagem Online: <http://www.meioemensagem.com.br>, Portal Exame: <http://www.exame.com.br>; Forbes Online: <http://www.forbes.com>, Los Angeles Times Online: $<$ http://www.latimes.com>; Chicago Online: http://www.chicagotribune.com>; Valor Online: <http://www.valor.com.br>, BBC Online: <http://www.bbc.com>, The New York Times Online: <http://www.nytimes.com>, The Wall Street Journal Online: <http://www.wsj.com>; Business Week Online: <http://www.businessweek.com>. Para não repetir essas 
referências online e não alongar ainda mais o texto omitiram-se as datas de acesso à fonte completa (acima apontada).

Houve um especial cuidado ao lidar com livros de negócios e com a imprensa focada nesse ramo: as declarações das companhias e empresários foram vistas com cautela quando afirmam pioneirismos - tendo sido preciso checar mediante outras fontes, ou desprezar certos dados. Por outro lado, às vezes, a imprensa especializada em negócios é excessivamente ácida em suas críticas, sendo igualmente necessário filtrar esse tom negativo. Correspondem a típicas tarefas de garimpagem da linha de pesquisa em História Empresarial, acima citada. Uma forma de lidar com esse risco foi a busca de mais de uma fonte - na medida do possível.

\section{RESULTADOS}

Tabela 1 - Critérios de categorização adotados e número de situações por categoria

\begin{tabular}{ccc}
\hline Quadro & Critério de Classificação & $\mathbf{N}^{\circ}$ de Situações \\
\hline 1 & Criação de redes de lojas por produtores ou prestadores de serviços & 50 \\
2 & Criação de lojas conceituais para reforçar a marca & 8 \\
3 & Abertura de lojas de fábrica & 2 \\
4 & Ingresso de fabricantes no atacado & 7 \\
5 & Ingresso de fabricantes no E-Commerce & 2 \\
6 & Ingresso no varejo em função de crises & 4 \\
7 & Ingresso no varejo mediante alianças ou redes de franquias & 7 \\
8 & Atuação de companhias focadas no luxo & 6 \\
9 & Aquisição de companhias já atuantes junto ao varejo & 8 \\
10 & Dificuldades enfrentadas por redes varejistas dos fabricantes & 5 \\
\end{tabular}

Fonte: Elaborado pelo autor, 2012.

Quadro 1 - Criação de redes de lojas por produtores ou prestadores de serviços

1) Em 1973, a Zara, fabricante de confecções, abriu sua própria rede de lojas (OPPERMAN, 2008).

2) Em 2004, a Sony criou uma rede varejista. Em 2008, contava com 200 lojas (STROSS, 2007; FACCHINI, 2008a; CRUZ, 2008; BOUÇAS; BORGES, 2009; TAUB, 2009).

3) A Apple foi uma das primeiras fabricantes de PCs a abrir suas próprias lojas, em 2001. Nos dois primeiros anos, a operação faturou US\$ 1 bilhão - maior resultado de um varejista nos EUA em tão pouco tempo. A partir de 2004, a Apple começou a abrir mínilojas. Em 2006, as 170 lojas venderam US\$3,3 bilhões - ou 17\% das receitas totais (HERZOG; MANO, 2007; STROSS, 2007; SCHWARTZ; CARMIEL, 2009).

4) Em 2007, a Motorola contava com cerca de 200 lojas, que vendem produtos sofisticados, como um aparelho projetado pela Dolce \& Gabbana (MAGALHÃES, 2006; HERZOG; MANO, 2007). 
5) Em 2007, a Nike somava 263 lojas. A empresa contava tanto com bandeiras com a bandeira Niketown e lojas de fábrica, mas, com finalidades distintas (HERZOG; MANO, 2007; OLIVAREZ-GILES, 2010).

6) A Matsushita inovou com os recém-lançados aparelhos de TV, lançando uma equipe de vendedores porta a porta, que visitou os camponeses do Japão. A marca chegou a 25 mil lojas National, vende as marcas Panasonic, Technics e Quasar. Metade das vendas nacionais da Matsushita é feita nessa rede (DRUCKER, 1991; AAKER, 1984; KEEGAN; GREEN, 1999; BOUÇAS; BORGES, 2009).

7) Nos anos 80, a Alcoa criou a rede TendTudo no Brasil - trazendo o formato dos home centers. Em 1987, contava com seis unidades, faturando US\$ 20 milhões ao ano (SILVA, 2001; BRITTO; WEVER, 2002).

8 e 9) A cervejaria Guinness criou uma rede de dois mil pubs, que replicam a experiência do pub. No Brasil, a Schincariol, ao adquirir a cervejaria Devassa, passou a ter uma pequena rede com 13 bares no Rio de Janeiro e um em São Paulo (BERTHON; HOOLBROOK, 2003; D’AMBROSIO, 2007).

10) O Corinthians contava com oito lojas próprias em 2009 (MADUREIRA; KOIKE, 2009).

11) Em 2008, a Häagen-Dazs contava com 12 sorveterias próprias no Brasil (HÄAGEN-DAZS..., 2008).

12) Em 1990 a Nutrasweet lança seu segundo produto, o Simplesse - pois estava apoiada apenas no aspartame. Como uma espécie de laboratório, a empresa criou um conceito de restaurante com cardápio formado por alimentos sem colesterol, com baixo teor de gordura e baixas calorias. (MCCANN, 1992).

13 a 15) No setor de cerâmicas, a espanhola Porcelanosa possui uma rede própria de lojas, que também vende metais, louças, móveis de cozinha e de banheiro. A Interceramic produz no México e nos EUA vende por atacado; no seu país, porém, vende apenas através de uma rede exclusiva, de 150 lojas próprias e franqueadas. A Datilde é uma produtora norte-americana com cerca de 200 lojas que atendem a pequenos e médios construtores. Além disso, vende aos home centers (SILVA, 2001).

16) Em 2006, a Puma inaugurou uma loja conceitual Black Label (BARONE, 2008a).

17) A Hankook, produtora coreana de pneus, e sétima em produção global, abriu lojas para atender o consumidor. Em 2008 eram 170 lojas na Coreia, e 7 na China, onde era o maior produtor (SALMON, 2008).

18) Anne Fontaine casou-se com Ari Zlotkin, cuja família produzia camisas. Anne desenhou uma coleção nova; em 1994, abriu-se a primeira loja - de uma rede que chegou a 70 unidades (BERGAMO, 2008).

19) A Orvis, produtora norte-americana de carretilhas de pesca, foi criada em 1856. De 1992 a 2008, as receitas triplicaram. Foram criadas mais de 60 lojas com a marca Orvis nos EUA e Grã-Bretanha, além de 400 revendedores no resto do mundo, e dois milhões de consumidores por catálogo (DUBOW, 2008).

20) A partir de 1996, a centenária Hering começou a criar uma rede de lojas. Em junho de 2009 detinha 39 lojas próprias e 205 franquias. Em setembro de 2009, a empresa já somava 258 lojas Hering e 64 com a bandeira PUC (TEIXEIRA, 2008; VALENTI, 2009a; VALENTI, 2009b).

21) A fábrica de chocolates Lindt \& Sprüngli iniciou exportações aos EUA em 1987, e começou a abrir lojas próprias em 1994, chegando a 80 lojas em 2009, das quais 50 fecharam com a crise (WIGGINS, 2009).

22) Em 2002, a centenária Casa Almeida - varejista de artigos de cama, mesa e banho - foi comprada pela Buddemeyer; passou-se a abrir uma loja por ano. Ao final de 2007, já eram cinco unidades (KOIKE, 2007a).

23) Fabricante de equipamentos esportivos, a Serelepe detém as marcas Kailash e Ultra Safe. A Kailash em 2005 abriu uma loja própria (COLOMBINI, 2008; KOIKE, 2008a).

24 e 25) A Nestlé mantém uma equipe de 4.000 vendedores que levam seus produtos à periferia de São Paulo e ao interior do estado. Segundo a empresa, essa seria apenas a melhor maneira de levar a marca até as classes C e D. Em 2008, já eram 6 mil vendedores na periferia paulista. A Nestlé também desenvolveu uma rede franqueada de 11 quiosques em estações de metrô da cidade de São Paulo e outros 18 dentro de unidades da Casas Bahia (HERZOG e MANO, 2007; COPPOLA, 2008).

26) A Whirlpool lançou em 2003 uma linha de purificadores de água distribuídos diretamente, num sistema semelhante ao de um aluguel. No ano seguinte, iniciou as vendas pela internet, com a marca Brastemp You, em que os consumidores podem personalizar seus produtos. Também lançou o sistema Compra Certa: 5.000 vendedores de 12 distribuidores carregam catálogos com produtos das marcas da Whirlpool e de outros fabricantes. Em 2006, o Compra Certa vendeu cerca de R\$ 400 milhões (HERZOG; MANO, 2007).

27) Em 2005, a Electrolux criou um sistema de venda direta ao consumidor, feitas por uma central telefônica e pela internet, as ofertas são divulgadas por meio do envio de cartas a públicos específicos, como funcionários da Caixa Econômica Federal (HERZOG; MANO, 2007).

28) Em 2006, a Johnson \& Johnson despachou carrinhos de venda de protetor solar da marca Sundown para 40 praias. Além disso, instalou um quiosque de vendas numa unidade do Poupatempo, centro de serviços à 
população mantido pelo governo, em São Paulo. Em dezembro de 2006, iniciou a venda de produtos por meio de um site próprio de relacionamento chamado Minha Vida (HERZOG; MANO, 2007).

29) A partir de 2003, a Ambev abriu 80 franquias para vender chope. Em 2005, inaugurou uma unidade um serviço que oferece o aluguel de chopeiras e a compra de chope a quem queira fazer uma festa; a rede chegou a sete unidades - sendo cinco franquias. Em 2006, levou 400 carrinhos munidos de chopeiras a praias. Os três formatos representaram 2\% do volume de chope vendido em 2006 (HERZOG; MANO, 2007).

30) Em 2008, a grife carioca Enjoy somava 40 lojas, sendo 22 franquias. Suas coleções focam as mulheres de 35 anos da classe B. No início dos anos 90 , a confecção cresceu focada em grandes varejistas, vendendo $80 \%$ para a Mesbla. Foi preciso um ano para se recuperar do impacto da quebra desse varejista. A empresa recomeçou com uma ponta de estoque no shopping Nova América (MAGALHÃES, 2008).

31) Em 2006, a Marisol adquiriu a grife de biquínis Rosa Chá. Em 2008, comprou 50\% da Blue Pink, varejista de roupas para bebê, e abriu sua 14a loja. A empresa viu um nicho: a Blue Pink visa à classe média enquanto a Lilica Ripilica e a Tigor T Tigre, focam a alta renda (JURGENFELD, 2008).

32) A produtora de cerâmicas Portobello iniciou a criação de uma rede de franquias, com a bandeira Portobello Shop, chegando a 75 lojas, em quase todos os estados brasileiros (NETO, 2005).

33) Herman Lundgren, produtor de tecidos de Pernambuco, iniciou a rede varejista Casas Pernambucanas quatro anos depois da criação da fábrica, e foi dos poucos fabricantes que conseguiram se livrar dos importadores por volta dos anos 40 (DEAN, 1991; FACCHINI, 2008b).

34) A BlackBerry abriu sua 1a loja em 2009, com dois mil complementos a seu produto (NOBREGA, 2009).

35) Em 2009, a Philips anunciou a abertura de lojas de lâmpadas na China e na Índia, visando vender seus modelos mais eficientes, de menor consumo, e maior rentabilidade (STERLING, 2009).

36) Para focar na exportação, a Ipanema Coffees vendeu 2 de suas 3 cafeterias para a Grão Expresso. A cafeteria restante foi transformada em um showroom para seus clientes (SCARAMUZZO, 2007).

37) O grupo Saint-Gobain ingressou no varejo de materiais de construção, comprando a Telhanorte, com 16 lojas em São Paulo, no ano 2000. Em 2007, a Telhanorte detinha 14 lojas na Grande São Paulo, seis no interior de São Paulo, três no Paraná e duas em Minas Gerais (URDAN; URDAN, 2005; KOIKE, $2007 c$ ).

38) O grupo Branco Peres iniciou exportações de café em 1995. Em 2006, o café do Centro abriu uma loja em Tóquio, meio a meio com sócios locais, dado que esse país é o terceiro maior consumidor mundial de cafés gourmet. Pouco depois, outra loja foi aberta, também na capital (ARAGÃO, 2008).

39) A torrefadora Café Tiradentes abriu duas cafeterias em Seul, entre 2006 e 2007 (ARAGÃO, 2008).

40) Em 2008, a Indústria Petroquímica do Sul que produz óleos básicos a partir do reprocessamento de lubrificantes usados, ingressou na venda direta ao varejo (BUENO, 2008a).

41 e 42) Em 2010, a Procter \& Gamble começou a abrir franquias de lojas de lavagem de roupas a seco. A P\&G oferece inovações como: cuidados ambientais, drive-thru, funcionamento 24 horas ao dia, e o atrativo de sua fragrância - reconhecida durante décadas nos lares dos EUA (MARTIN, 2010).

43) Em 1986, a fábrica de brinquedos Trol foi ao varejo, comprando a rede Dukinha (LAS CAZAS, 2001).

44) A Azaléia adotou o modelo de lojas próprias e exclusivas, com as bandeiras Azaléia e Olympikus, chegando a 18 do primeiro tipo e 71 do segundo (D’AMBROSIO, 2005; BUENO, 2006).

45 a 47) A Bibi, fabricante de calçados infantis, inaugurou em 2008 uma loja-conceito própria. Depois foram abertas outras lojas próprias e franqueadas. A mineira Arezzo tem lojas franqueadas desde 1990, chegando a 223 unidades em 90 cidades, vendendo cerca de 3 milhões de pares. A Via Uno, de Novo Hamburgo (RS), adotou o modelo de franquias em 2005 e chegou a 151 no Brasil e 85 em 21 países (BUENO, 2008b).

48) Em 2003 a Melissa criou um site para o mercado externo, associou-se a designers, colocou seus produtos em lojas famosas, e começou a anunciar em revistas de vanguarda. Abandonou as feiras de calçados para expor em feiras de design. Em 2008, estava em cerca de 40 países. Abriu uma loja-conceito em São Paulo. 0 número de pontos de venda passou de 25 em 2006 a 250 em 2008 (BARONE, 2008b; FERNANDES, 2008).

49) A Couroquímica trata duas mil peles ao dia, utilizando parte delas para a produção de bolsas e calçados, vendidos em lojas com a bandeira Carmem Stieffens - rede criada em 1994 - com 130 pontos no país e 18 no exterior. Em 2008, as lojas estrangeiras responderam por $8 \%$ das receitas (BARONE, 2009).

50) Em 2011, a Samello abriu sua segunda loja em Brasília. A empresa exportava para 35 países e fazia coleções para marcas famosas como a Prada. Em outubro de 2006, a tradicional empresa familiar - já em sua terceira geração - chegara a suspender suas operações (BUENO, 2006; SAMELLO..., 2011).

Fonte: Elaborado pelo autor, 2012. 
O Quadro 1 impressiona pela quantidade: 53 situações. A Enjoy ilustra o peso do varejo: uma confecção que produz cem mil peças/mês, porém, sendo $80 \%$ vendidas a um só varejista enfrentou um risco acima do suportável. Havendo expertise para unir produção e gestão de uma rede varejista - franquias, lojas próprias, ou uma combinação de ambas - os riscos são minimizados, e a empresa deixa de depender de grupos varejistas, cada vez mais fortes, e que, por sua vez, estão investindo de modo crescente na criação de suas marcas próprias.

Outra situação rica: o rápido crescimento da Devassa no Brasil poderia merecer estudos visando aferir o quanto dependeu de suas lojas próprias. A situação da Samello também é emblemática: apesar de estar na terceira geração, possuir ótimos produtos, exportar a diversos países, em seu próprio mercado de origem o poder de inúmeras redes multimarcas fez com que a Samello não mais estivesse em condições de ditar as regras. Eventualmente, sem intenções de se fazer uma afirmação academicamente ideal ou cabal, a Samello e outros produtores de calçados sofreram por concorrentes como a Mr Cat, dotada produção própria de calçados, e mais uma rede de cem lojas próprias nos principais shopping centers do país e mais cem lojas franqueadas. Há que se destacar a elevada qualidade do atendimento nas lojas Mr Cat, com as atendentes todas de nível universitário, uniformizadas, e os clientes recebendo um par de meias de algodão no caso da venda à vista - um raro caso de brinde para esse tipo de situação. Ou seja, a situação da Mr Cat ilustra o sucesso de uma situação de verticalização a jusante - como objetivo do artigo.

Quadro 2 - Criação de lojas conceituais para reforçar a marca

1) Em 2005, a Samsung inaugurou sua primeira loja própria no Brasil, exibindo mais de 100 produtos da marca inclusive modelos disponíveis apenas na Coreia. A loja não vende para não competir com os lojistas (SAMSUNG..., 2005; CRUZ, 2008).

2) Em 2005, a Heineken abriu um restaurante, Culture Biere, em Paris. Em 2007, abriu um bar no aeroporto de Hong Kong (NESPRESSO..., 2007).

3) A TAM abriu uma loja para seus funcionários escolherem os mais de mil itens de uniformes da marca. Realçou-se a importância da retirada desses itens como uma experiência única de contato com a empresa e seus valores (MACHADO, 2009).

4) A produtora francesa de joias Maubossin detinha 180 anos de tradição antes de abrir uma megastore em New York; já detinha cinco lojas pelo mundo; além de vender em 200 butiques (WILSON, 2008).

5) A BM Sua Casa, área de financiamento imobiliário da Brazilian Securities, possui 47 lojas. A empresa financia a aquisição de terrenos; compra ou reforma de imóveis (D’AMBROSIO, 2008).

6 e 7) Em 2005, a Natura abriu sua primeira loja, em Paris (FERNANDES, 2005). Em 2011 abriu um espaço em 
um shopping, um local de atividades gratuitas ao público e de exposição de produtos (MATTOS, 2011).

8) A italiana Technogym atua em cerca de 100 países, atendendo academias, hotéis e spas, vilas olímpicas, times de futebol e pilotos de Fórmula-1. Passou a focar o usuário que monta uma academia em casa (MADUREIRA, 2009).

Fonte: Elaborado pelo autor, 2012.

As oito situações do Quadro 2 são criativas, destacando-se a Natura, com duas iniciativas distintas, uma voltada ao público nacional, com exposição de seus produtos e realização de eventos; porém, sendo a outra focada no fortalecimento internacional de sua marca - dado que os principais players internacionais já se encontravam em atuação no país, portanto era necessário fortalecer esse flanco, uma tarefa de respeitável dificuldade.

Quadro 3 - Abertura de lojas de fábrica

1) A G. H. Bass vendia seus sapatos e outros produtos apenas pelo varejo; começou a abrir lojas de fábrica, mantendo, porém, os canais existentes (GRIFFIN, 1996).

2) A Vila Romana abriu uma loja ao lado de sua fábrica. Com o tempo, deixou de vender às lojas multimarcas e criou uma rede de lojas próprias - que podem ser classificadas de category killers por oferecerem preços altamente competitivos (MINADEO, 2005; VAN DEN BROEK, 2007).

Fonte: Elaborado pelo autor, 2012.

No Quadro 3, apresentam-se duas situações de criações de redes de lojas de fábrica. A marca Vila Romana é típica da migração para lojas das próprias fábricas, pois enfrentou problemas nas lojas multimarcas, e a experiência inicial de uma loja própria ao lado da fábrica veio a se tornar um padrão para a abertura da rede e para não mais se depender das multimarcas.

Quadro 4 - Ingresso de fabricantes no atacado

1) Em 1919, a Procter \& Gamble recebia grandes pedidos dos atacadistas, porém, sem qualquer periodicidade, causando problemas para estabilizar seu volume de produção e manter empregos estáveis ao seu pessoal. Começou a vender diretamente aos varejistas (COLLINS; PORRAS, 2000, p. 155).

2) Na década de 50, a Sadia - controladora do Frigorífico Concórdia e do Moinho Lapa - em associação com capitais gaúchos, lançou suas próprias distribuidoras em São Paulo e no Rio de Janeiro (AQUINO, 1991).

3) As baterias Moura apenas retomaram o crescimento após os anos 80 , ao criar 40 centros de distribuição, associado a empresários locais - chegando a deter 40\% do mercado de reposição do país (MORAIS, 1999). 4 a 7) Em 2008, a ArcelorMittal adquiriu participação em duas empresas de distribuição: Manchester Tubos (70\%) e Gonvarri (50\%). Em 2008, a Usiminas adquiriu a gaúcha Zamprogna, distribuidora de aço e fabricante de tubos de aço. (PACHECO, 2008). Em 2008, a Usiminas adquiriu os $49 \%$ que a ThysenKrupp detinha na Dufer, distribuidora e transformadora de bobinas, passando a deter 100\% do negócio (CAMAROTTO, 2008).

Fonte: Elaborado pelo autor, 2012. 
O Quadro 4 apresenta sete situações, destacando-se o ingresso de diversos grupos siderúrgicos no atacado; mostrando o interesse das siderúrgicas se aterem ao negócio em que detém suas tecnologias básicas, porém, ingressando na oferta de aços prontos para uso pelas construtoras, metalúrgicas e demais usuários finais. Além disso, há uma operação bastante sui generis: a criação de um setor atacadista pela Sadia visando penetrar mais rapidamente nos mercados do Sudeste, por estar centrada no interior catarinense, região de menores possibilidades de crescimento. A verticalização rumo ao atacado propiciou elementos para a Sadia enfrentar os maiores players do setor, e obter significativas vantagens comparativas.

\section{Quadro 5 - Ingresso de fabricantes no E-Commerce}

1) Lançou-se a Lego Factory em 2005, permitindo que os usuários façam download de software para projetar seus modelos, pedi-los à Lego e disponibilizá-los a outras pessoas. Milhares de modelos foram criados e alguns tornaram-se produtos oficiais da Lego, e os produtores recebem royalties (ANDERSON, 2006).

2) Mediante a App Store, a Apple passou a vender aplicativos pela web; em 2008, o proprietário médio de um iPhone adquiriu 15 aplicativos, enquanto que os da Nokia ou Motorola não adquiriram nenhum; em seis meses, foram criados mais de dez mil aplicativos (BURROWS, 2009).

Fonte: Elaborado pelo autor, 2012.

As duas situações do Quadro 5 são bem criativas, além de já apontarem resultados que viabilizam os investimentos realizados. A Apple tem sido objeto de inúmeras reportagens em função da perda de seu Presidente há cerca de seis meses; cabe destacar que a abertura de suas lojas foi crucial para romper a barreira que muitos consumidores detinham em julgar os produtos da marca sendo de uso mais difíceis do que os usuários dos sistemas operacionais Microsoft - daí a existência de inúmeros consultores nas lojas para mostrar aos potenciais clientes que os produtos Apple não possuem essa dificuldade.

Quadro 6 - Ingresso no varejo em função de crises

1 e 2) Nos anos 70, a produtora de cristais Swarovski enfrentou uma crise, e passou a abrir lojas. Em 2005, o varejo representou quase $50 \%$ do negócio, com 600 lojas. Além disso, 7 milhões de pessoas passaram pelo Kristallwelten - um parque temático em torno aos seus produtos (MUITO..., 2006; KOIKE, 2008c) 3) Em 2008, a Camargo Corrêa Desenvolvimento Imobiliário abriu uma loja no Shopping Jardim Sul. A loja foi motivada pela lei que impediu os outdoors em São Paulo e pela crise do setor (D’AMBROSIO, 2008).

4) Em 2009, a Coteminas-Springs adquiriu a MMartan, ingressando no varejo, visando contornar os problemas gerados pela aquisição da Springs - que coincidiu com a crise global (A SPRINGS..., 2010). Fonte: Elaborado pelo autor, 2012. 
O Quadro 6 apresenta quatro situações de verticalização ocasionadas por crises. Destaca-se a Swaroski, que não apenas abriu uma formidável rede de lojas como também um parque temático - uma solução que pode ser considerada extremamente criativa: à medida que os consumidores potenciais visitam o parque, independentemente dos efeitos nas vendas imediatas, recebem o forte impacto a respeito da marca. Em outras palavras, a visita ao parque temático representa uma imersão no próprio "branding" da empresa.

Quadro 7 - Ingresso no varejo mediante alianças ou redes de franquias

1) Em 2008, a Faber Castell se associou à ONG Doutores da Alegria para levar os produtos com essa marca à Livraria Cultura, dos quais a ONG recebe $15 \%$ das receitas. A ONG é formada por atores e é especializada no entretenimento de crianças (KOIKE, 2008b).

2) Em 2008-9, associada a revendas, a Hewlett Packard (HP) abriu 17 lojas, oferecendo produtos de consumo. A HP apoia a montagem dos ambientes (BRIGATTO, 2008; BOUÇAS; BORGES, 2009).

3) Em 2009, a Victoria's Secret iniciou um novo formato, geridas pela Dufry, operadora de mais de mil lojas em aeroportos e navios. As primeiras lojas foram abertas em New York e São Paulo (FACCHINI, 2009).

4) A Prodent, operadora de planos de saúde odontológicos, teve sua receita crescendo de $R \$ 21$ para $R \$ 43$ milhões entre 2008 e 2009, em função de acordos com diversas redes varejistas (KOIKE, 2010).

5) Minadeo (2008a e 2010) apresenta a aliança criada entre o atacadista Martins e centenas de pequenos varejistas, criando-se a rede Smart, com o conceito de fortalecer seus clientes, face ao acelerado crescimento das maiores varejistas do setor e do fato de estarem adquirindo inúmeras redes de atuação regional - desse modo, o setor varejista é palco tanto de sistemas logísticos avançados quanto de alianças estratégicas.

6) O projeto Montana Grill Premium Beef iniciou-se em 2001, como uma aliança as churrascarias Novilho de Prata, Pampeana e Boi Brasil, e a dupla Chitãozinho e Xororó. Houve assessoria do Fundo de Desenvolvimento da Pecuária na criação de um padrão para a certificação dos novilhos. O projeto atua com parceiros do Frigorífico Marfrig, e chega ao varejo: uma rede de churrascarias, lojas fast food (Montana Grill Express) e a boutique de carnes Montana Carnes e Cia. Também criou-se a marca Montana Premium Beef, vendida em alguns supermercados. A produção de carne é focada em cortes embalados a vácuo e maturados por no mínimo 15 dias, o que confere o diferencial de maciez e suculência dos produtos (MACEDO, 2009).

7) O Lipitor, o remédio mais vendido de todos os tempos, rendeu à Pfizer receitas de mais de US\$ 81 bilhões desde que foi lançado, em 1997. Temiam-se trocas pelos genéricos ao término da proteção da patente, em 30/11/2011. Para evitar isso, a Pfizer fez uma parceria com a Diplomat Specialty Pharmacy, que envia o Lipitor pelo correio a quem pedi-lo diretamente pela rede. A Diplomat então envia a conta ao plano de saúde dos pacientes. Os planos que fecharem acordo com a Pfizer pagarão pelo Lipitor o preço do genérico, vantagem não estendida aos demais planos (ROCKOFF, 2011).

Fonte: Elaborado pelo autor, 2012.

Das sete situações apresentadas no Quadro 7, a Prodent foi criativa e obteve crescimento significativo em sua presença no mercado. Ao mesmo tempo, a criação da bandeira Smart é sui generis: segundo o autor, o atacadista Martins se viu ameaçado em função de inúmeras redes de porte médio e pequeno - seus clientes serem adquiridas pelas grandes redes nacionais, que adquirem diretamente junto aos 
produtores. Em outras palavras, a criação da bandeira Smart foi um movimento de verticalização defensivo, com a função de criar seu próprio canal varejista, e, assim, depender menos dos clientes já existentes - potenciais alvos a serem adquiridos pelas grandes redes nacionais.

Apresenta-se também uma criação de rede mediante complexas alianças entre vários parceiros. Trata-se dos diversos negócios que estão na base da Montana Grill: rede de churrascarias, rede de fast-food e oferta de produtos Premium a duas redes supermercadistas - tendo havido um apoio de um Fundo Estadual de Desenvolvimento da Agropecuária. O próprio estudo no qual foi encontrada a situação descrita. Macedo (2009) aponta a dificuldade de frigoríficos poderem verticalizar suas atividades em função dos elevados volumes de capital exigidos. Dessa forma, uma aliança que permitiu uma situação de verticalização, e que envolveu inclusive um organismo governamental pode ser considerada uma situação bastante criativa para ampliar os negócios.

A Pfizer fez uma drástica redução do preço do Lipitor, em sua aliança, igualando-o ao dos genéricos, porém, enviando o medicamento diretamente aos clientes, buscando idealizá-los.

Quadro 8 - Aquisição de companhias já atuantes junto ao varejo

1) A EMC, maior fabricante de produtos de armazenagem de dados do mundo, porém, focada no ambiente corporativo, ingressou no varejo, em 2008, pela aquisição da lomega, fabricante de produtos de armazenamento para o consumidor final, por US\$ 213 milhões. Em seguida, fez acordos com as grandes redes de varejo do país, em vez de limitar-se a revendas especializadas (BORGES, 2009).

2 e 3) Em 2006, a L'Oreal adquiriu por US\$1,14 bilhão a Body Shop, rede de lojas de cosméticos criada pela lendária empreendedora Anita Roddick. Também adquiriu a Kiehl's, produtora de cosméticos sofisticados e com loja em New York. O presidente da empresa julga importante em um momento de crise o fato de deter lojas próprias (BODY..., 2009; WIGGINS; DANESHKHU, 2009).

4) Em 2002, a UPS adquiriu a Mail Boxes Etc., por US\$ 180 milhões. Com essa operação, a UPS abriu um novo canal de distribuição para seus serviços - dotado de 4,3 mil lojas (COPELAND, 2007).

5) Em 2004, a FedEx reagiu à compra da Mail Boxes pela UPS, e adquiriu a Kinko's, rede de lojas de serviços de cópia e impressão, por US\$ 2,4 bilhões. A Kinko's fora criada em 1970, por Paul Orfalea, e, ao ser comprada pela FedEx, somava 1.200 lojas em todo o mundo, conectadas por uma rede digital, e 20 mil funcionários. Nos seus primeiros 20 anos, a Kinko's chegara à posição de maior rede do setor de fotocópias. Em 2002, as receitas da Kinko's foram de US\$ 2 bilhões (COPELAND, 2007).

6) Em 2011, a Lenovo adquiriu a alemã Medion, varejista de eletrônicos, visando expandir sua atuação em países desenvolvidos (LENOVO..., 2011).

Fonte: Elaborado pelo autor, 2012. 
No Quadro 8 se apresentam seis aquisições de varejistas por parte de produtores. Destaca-se a aquisição de uma rede de venda de produtos eletrônicos por parte da chinesa Lenovo, ao lado das duas aquisições da L'Oreal de marcas mundialmente reconhecidas, e que trouxeram novos nichos de atuação a essa produtora já tradicional e presente em inúmeros outros canais de distribuição mediante suas demais marcas e linhas de produtos.

Quadro 9 - Atuação de companhias focadas no luxo

1) A gaúcha Altero produz metais de luxo para banheiros, puxadores e maçanetas. Possui linhas assinadas por arquitetos de renome e oferece garantia de 12 anos para todos os produtos. Em 2006, abriu sua primeira loja, na capital paulista (BUENO, 2007).

2) A Nestlé lançou Nespresso em 1986. O café é servido em sachês de alumínio, e só podem ser usados nas máquinas vendidas na loja. As receitas da Nespresso em 2008 somaram cerca de US\$1,7 bilhão, atuando em 50 países, com 175 cafeterias - que vendem máquinas domésticas de café variando de $€ 149$ a $€ 1.849$. Assim, enquanto a Starbucks é tida como a criadora do padrão das cafeterias, a Nespresso é a lançadora do café premium, vendido em grandes quantidades. Em 2008, Em 2011, foi lançada a Pixie. Em 2012 lançou a Lattissima+, que prepara expressos longos e curtos, mas também cappuccinos e machiatos (MALTA, 2007; MAGALHÃES, 2007; NESPRESSO..., 2007; SALTMARSH, 2009; CAPPUCCINOS..., 2012).

3) A marca de produtos de luxo Chanel abriu sua primeira loja, apenas de chapéus, em 1909, em Paris. A rede que somava apenas 20 lojas no início dos anos 80, chegou a 2009 com 170 lojas (FERNANDES, 2009).

4, 5 e 6) Em 2009, a produtora suíça de relógios Villemont faliu. As exportações do país nos primeiros nove meses do ano caíram 26\%. Os produtores Roger Dubuis, IWC e Audemars Piguet abriram lojas em Shanghai, Hong Kong e New York - respectivamente (GOMELSKY, 2009).

7) Em 2009, a Lamborghini abriu uma revenda própria na Califórnia, de modo a apresentar sua linha completa e ficar mais próxima ao consumidor (CHANG, 2009).

8) Em 2011, a Harley-Davidson iniciou operações próprias no Brasil mediante uma estrutura direta de comando e controle sobre a rede de lojas, tendo rompido seu relacionamento com o importador - o grupo Izzo. Além disso, 13 modelos da marca eram montados em Manaus (RIBEIRO, 2011).

Fonte: Elaborado pelo autor, 2012.

No Quadro 9, um destaque é o da Nespresso, que em poucos anos conseguiu se transformar em um importante negócio adicional dentro de um grupo já de porte respeitável como a Nestlé - um resultado francamente difícil -, o que ilustra graficamente a importância e a atualidade do tema da verticalização a jusante e do ingresso no varejo de grupos industriais. O lançamento de novos aromas, novas marcas e a abertura de lojas em pontos luxuosos são típicos elementos que contribuíram para a criação de valor à marca, e ao sucesso da verticalização - levando milhões de consumidores a deterem em suas residências máquinas que apenas fazem 
uso de cápsulas fornecidas pela Nestlé. Com essa estrutura, ficou-se menos vulnerável à força dos grandes varejistas de cafés prontos.

Quadro 10 - Dificuldades enfrentadas por redes varejistas dos fabricantes

1) Em 2009, a Nokia anunciou o fechamento de lojas em Chicago, New York e de duas lojas em Londres, de sua rede total de 12 unidades (NOKIA TO..., 2009).

2) Em 2011, a grife italiana Diesel fechou suas três lojas próprias no Brasil. Inaugurada em 2008 com a presença do dono da marca, a loja da rua Haddock Lobo, era o maior do grupo no mundo, com espaço de 1.700 metros quadrados. A Diesel manteve-se presente em cerca de 100 pontos multimarcas espalhados pelo país (BRUNNING, 2011).

3) Alguns anos atrás, a Danone fez testes de sistemas de venda porta a porta, mas problemas logísticos inviabilizaram o projeto (HERZOG; MANO, 2007).

4) Em 2009, a Mars fechou cinco das seis lojas conceituais Ethel's Chocolate Lounge, da área de Chicago, onde ingressara em 2006. Anunciou que as 8 lojas de Las Vegas permaneceriam abertas (ETHEL'S..., 2009).

5) A Gateway abriu uma rede com a bandeira Country Stores, não possuía estoques, e funcionava como um mostruário, para o consumidor fazer as compras de computadores, e depois, esperar a entrega. Em 2004, a Gateway descontinuou as operações, que haviam chegado a 188 lojas (STROSS, 2007).

Fonte: Elaborado pelo autor, 2012.

O Quadro 10 aponta 5 empresas que tiveram dificuldades em suas redes varejistas. Torna-se importante para qualquer estudo procurar mostrar esse tipo de contrapontos, dado ao fato de que a realidade efetivamente traz luzes e sombras, e não existem receitas fáceis ou completamente garantidas de sucesso no mundo empresarial. Em outras palavras, o mesmo empenho alocado na busca das situações dos quadros anteriores - que podem ser considerados de sucesso - também foi aplicado em se apontar situações nas quais não ocorreram os sucessos positivos esperados. Essa medida visa tornar mais neutra e acadêmica a pesquisa gerada ao longo de toda a confecção do artigo. Destacam-se as tentativas da Danone em criar uma rede de vendas focada no porta a porta, para combater a tradicional rede da concorrente Yakult e o fracasso da produtora de PCs Gateway, que chegou a 188 lojas, porém, apenas para apresentar o produto; desse modo, fazia-se necessária uma nova etapa ao eventual consumidor interessado: a aquisição. Ora, em função da pronta disponibilidade de PCs em inúmeras redes de lojas especializadas em produtos eletrônicos ou de lojas da concorrência, esse modelo se viu definitivamente sem praticidade alguma. 


\section{CONSIDERAÇÕES FINAIS}

Os diversos quadros permitem aferir que o varejo se constitui em uma poderosa força, em função de sua proximidade com o cliente - trazendo maior força ao fabricante à medida que o torna menos vulnerável ao varejo, que, por sua vez, ataca mediante o lançamento de marcas próprias e de contínuas e crescentes exigências para que as marcas tenham espaço em suas gôndolas. Ou seja, inúmeras companhias vislumbraram uma incursão no varejo não apenas para verticalizar a jusante, mas visando a: a) deixar de depender de lojas multimarcas; b) não mais estar à mercê das inúmeras pressões dos grandes varejistas - cujo lançamento de marcas próprias é crescente; c) diminuir seus gastos publicitários, à medida que se possui presença física em locais onde os consumidores se encontram, ou seja, a exposição dos produtos (merchandising) ganhou maior importância; e d) possuir contato direto junto ao consumidor, obtendo mais dados sobre ele e seus hábitos.

Motta e Silva (2006) apontam algumas recentes mudanças no varejo, como a: a) globalização das grandes redes; b) consolidação das redes supermercadistas; c) surgimento de novos formatos; d) lançamento de marcas próprias (*); e) criação de centrais de negócios por pequenos varejistas; f) concorrência entre varejistas de distintos formatos; e g) lançamento do varejo on-line. Vários desses itens se observaram nos quadros acima, como: c) surgimento de novos formatos (Victoria's Secret e Montana Grill, Quadro 7); d) lançamento de marcas próprias (Criação de Lojas Conceituais de Marcas, quadro 2); e g) (Lego e Apple, Quadro 5)

O sucesso de um varejista depende de incorporar o conceito do varejo, que é uma orientação da gestão que foca a determinação das necessidades dos mercadosalvo e a satisfação dos clientes de modo superior ao da concorrência (CRESCITELLI et al., 2006). Esse conceito se nota em inúmeras das situações apontadas, ou seja, que conseguiram consolidar o conceito varejista. Novamente, o exemplo da Apple é estelar - ao lado da criação da Nespresso, que se pode até considerar mais articulada, pois não é apenas uma rede varejista criando algo já existente, porém é uma rede da Nestlé para comercializar um novo conceito: máquinas de café (sem deixar também de 
ofertar cafés premium) para os clientes que querem tê-las em suas residências e que passam a adquirir os suprimentos da fábrica.

Em que pese o surgimento do E-Commerce, as inúmeras situações acima apontam que a presença física dos consumidores nas lojas faz parte do processo mercadológico, variando em intensidade de produto para produto: assim, aquilo que pode ser digitalizado, como a música, se constituiu em uma oportunidade para a Apple - que superou o maior varejista do mundo na venda de músicas no maior mercado mundial. Porém, inúmeros outros produtos não podem ser digitalizados. Assim, o varejo se fortalece à medida que possa: a) apresentar uma rica experiência ao consumidor; b) encantá-lo mediante a qualidade do atendimento; e c) prestar inúmeros outros serviços.

Conceitos cruciais no modelo de negócio varejista: a) as redes primariamente vendem artigos feitos por outros; assim, um foco em sortimento provavelmente trará vantagens comparativas, pois produtos iguais estão disponíveis por toda a parte; e b) os varejistas interagem com os consumidores finais, diferentemente dos fabricantes; assim, podem construir relacionamentos duradouros. (SORESCU et al., 2011). Contudo, o ingresso no varejo se constitui uma forma de diferenciação e também de construir relações estáveis com o consumidor final conforme a situação da Apple ilustra claramente. Ao mesmo tempo, as ideias de Silva e Batalha (2001) sobre as vantagens da integração vertical em parte ligada à apropriação dos ganhos dos mercados a jusante da atividade original da empresa foram corroboradas amplamente.

O artigo apontou inúmeras situações de ingresso de fabricantes ou prestadores de serviços no varejo. A variedade e as características inovadoras de várias delas conferem riqueza, e se constituem em um ativo do estudo. Ao mesmo tempo, as diversas classificações encontradas apontam para possíveis fontes de ideias a empresas que queiram ingressar no varejo.

Limitações do estudo: a) resultados não podem ser generalizados; b) o problema da pesquisa pode envolver variáveis não investigadas; c) pode ter havido falhas na interpretação e/ou na classificação em categorias dos dados coletados; e d) o 
estudo se apoiou em dados secundários, desse modo, poderiam ser feitos estudos de casos com profundidade, indo-se direto a algumas companhias que se destacaram pelo ingresso no varejo. Essa vulnerabilidade se constitui, por outro lado, em um aspecto positivo: se não fossem filtradas cuidadosamente as situações aqui apontadas, teria sido impossível (a menos que houvesse um volume imenso de recursos; uma equipe dotada de tempo bastante razoável e a correspondente recepção dos pesquisadores por parte das empresas - algo nem sempre correspondente à cultura nacional) a obtenção da riqueza do material aqui apresentado. Em outras palavras, a busca de dados secundários - apoiada em uma sólida linha de História Empresarial - possui seu papel, conforme apontado na metodologia, e o artigo contribui para mostrar algumas tipologias de verticalização no varejo, bem como a riqueza de inúmeras situações apontadas nos diversos quadros, emanadas nas conclusões deles.

Outros estudos poderiam comparar o desempenho de produtores com o de prestadores de serviços em suas incursões varejistas. Em função das dificuldades vividas em épocas de crise por inúmeras redes varejistas, poder-se-ia estudar se aqueles grupos verticalizados são menos vulneráveis. Ainda caberiam estudos aprofundados em certos setores da economia, visando aferir o poder do varejo em relação à penetração do E-Commerce.

\title{
STRATEGY VERTICALIZATION DOWNSTREAM: ENTRY OF PRODUCERS IN RETAIL
}

\begin{abstract}
Faced with intense competition, it is increasingly vital the need to establish competitive advantages in order to keep the company with superior offerings to consumers in relation to the other competitors. The present paper classifies some situations of vertical and producers of goods and services into the retail market. The relatively recent entrance of several groups in retail activities not seems to be a fad like other business moves that were to
\end{abstract}


be proved as ephemeral and poorly understood. The purpose of this paper is to present to producers of goods and services some interesting strategies practiced in the process of going to retail. Another purpose of the article is in the presentation of numerous situations - with a very rich kind of variety showed by several companies in his approach to the market in these pursue to survive and growth. Another phase of the paper classifies the situations that were founded in 12 types. Finally, the Conclusions analyses all the 12 types.

Key-words: Business Strategy. Retail. Vertical Integratioon Strategy.

\section{REFERÊNCIAS}

AAKER, D. Strategic market management. New York: John Wiley \& Sons, 1984.

ANDERSON, C. A cauda longa. Rio de Janeiro: Campus, 2006.

ARAGÃO, M. O desafio de construir uma marca no exterior. O Estado de São Paulo, 28 jul. 2008, Caderno Economia, p. B11.

AQUINO, C. História empresarial vivida, Vol. V. São Paulo: Editora Atlas/Gazeta Mercantil, 1991.

A SPRINGS ganha um banho de loja. O Estado de São Paulo Online, 10 mai. 2010.

BARONE, V. Puma lança linha cara e dobra rede até 2011. Valor Online, 03 set. 2008a.

BARONE, V. Melissa, da Grendene, vira acessório fashion lá fora. Valor Online, 05 set. 2008b.

BARONE, V. Couroquímica amplia rede de lojas da marca Carmen Steffens. Valor Online, 23 abr. 2009.

BERGAMO, M. Copo de leite. Folha de São Paulo, 21 dez. 2008, Caderno llustrada, p. E2. 
BERTHON, P.; HOOLBROOK, M. B. Understanding and managing the brand space. MIT Sloan Management Review, winter/2003, p. 49-54.

BODY Shop chain to CUT 175 jobs. BBC Online, 27 fev. 2009.

BONI, Valdete; QUARESMA, Sílvia Jurema. Aprendendo a entrevistar: como fazer entrevistas em Ciências Sociais. Florianópolis: Em Tese, Revista Eletrônica dos PósGraduandos em Sociologia Política da UFSC, v. 2, n. 1, jan.-jul/2005, p. 68-80.

BORGES, A. Para EMC, chegou a hora de conquistar o consumidor final. Valor Online, 21 jan. 2009.

BOUÇAS, C.; BORGES, A. Lojas próprias fortalecem marcas de TI. Valor Online, 10 dez. 2009.

BOWDEN, W. The industrial history of the United States. New York: Adelphi Company Publishers, 1930.

BRIGATTO, G. HP adota lojas próprias para reforçar presença no varejo. Valor Online, 10 dez. 2008.

BRITTO, F.; WEVER, L. Vivendo, aprendendo \& ensinando. São Paulo: Negócio Editora, 2002.

BRUNING, F. V. Grife italiana Diesel fecha lojas próprias no Brasil. Folha Online, 28 mai. 2011.

BUENO, S. Britto deixa o comando da Azaléia. Valor Online, São Paulo, 05 dez. 2006. Acesso em: 01 ago. 2007.

BUENO, S. A gaúcha Altero prevê mais 15 lojas em 2008. Valor Online, 25 set. 2007.

BUENO, S. IPS amplia atuação e vai atender consumidor final. Valor Online, 18 nov. 2008a.

BUENO, S. Indústria de calçados aumenta sua rede varejista. Valor Online, $26 \mathrm{dez}$. 2008b.

BURROWS, P. Com App Store, Apple mostra porque a união faz a força. Valor Online, 21 jan. 2009.

CAMAROTTO, M. Usiminas compra 49\% da Dufer e acelera consolidação da distribuição. Valor Online, 08 out. 2008. 
CAPPUCCINOS e machiatos ao toque de um botão. Brasília: Hoje em Dia, v. 777, 24 mar. 2012, p. 15.

CASAROTTO FILHO, N.; CASTRO, J. E. E.; FIOD NETO, M.; CASAROTTO, R. M. Estratégias empresariais e competitividade para pequenas empresas: os mecanismos de redes. ABEPRO, Anais do ENEGEP, 1998. Disponível em: <http://www.abepro.org.br/biblioteca/ENEGEP1998_ART198.pdf>. Acesso em: 27 jun. 2011.

CHANDLER, Alfred D., Jr. 1962, Strategy and Structure: Chapters in the History of the American Industrial Enterprise. Cambridge, MA: MIT Press.

CHANG, A. Lamborghini opens its first stand-alone U.S. retail boutique. Los Angeles Times Online, 02 dez. 2009.

COLLINS, J. C.; PORRAS, J. I. Feitas para durar - práticas bem-sucedidas de empresas visionárias. Rio de Janeiro: Rocco, 2000.

COLOMBINI, L. A hora do confronto. Portal Exame, 20 out. 2005. Acesso em: 26 Mai. 2008.

COPELAND, M. Assim na terra como no céu? HSM Management, v. 61, marçoabril/2007, p. 62-69.

COPPOLA, M. Lições da base da pirâmide. Época Negócios, v. 2, n. 17. Jul. 2008, p. 28 29.

CRESCITELLI, E.; GUIMARÃES, C. T.; MILANI, G. F. Marketing de relacionamento aplicado ao varejo: uma proposta de fidelização. Revista de Administração da

UNIMEP, v. 4, n. 1, jan./abr. 2006, p. 17-37.

CRUZ, R. As lojas próprias de eletrônicos. O Estado de São Paulo Online, 14 dez. 2008.

D’AMBROSIO, D. Calçadista adota loja própria para crescer no exterior. Valor Online, São Paulo, 12 jan. 2005. Acesso em: 01 ago. 2007.

D’AMBROSIO, D. Schincariol estreia em sucos prontos para beber. Valor Online, São Paulo, 25 set. 2007.

D'AMBROSIO, D. Lojas em shoppings para ficar mais perto do cliente. Valor Online, São Paulo, 29 dez. 2008.

DEAN, W. A industrialização de São Paulo. Coleção Corpo e Alma do Brasil. Rio de Janeiro: Editora Bertrand Brasil, 4ạ Edição, 1991.

DRUCKER, P. Inovação e espírito empreendedor. São Paulo: Pioneira, 1991.

DUBOW, C. Orvis' Hot Rod. Business week online, 11 dez. 2008. 
ETHEL'S Chocolate Lounge closing 5 of 6 Chicago-area locations. Chicago Tribune Online, 07 abr. 2009.

FABIANO, L. Relacionamento como fonte de vantagem competitiva sustentável: um estudo entre fabricantes de móveis e lojas exclusivas. Dissertação (Mestrado em Administração). Porto Alegre: UFRGS, 2005.

FACCHINI, C. Sony, que já tem 200 lojas pelo mundo, abre a primeira no Brasil. Valor Online, São Paulo, 18 mar. 2008a.

FACCHINI, C. Casas Pernambucanas, discreta e lucrativa. Valor Online, São Paulo, 14 nov. 2008b.

FACCHINI, C. Victoria's Secret testa o Brasil com loja em Cumbica. Valor Online, 27 ago. 2009.

FERNANDES, D. Natura estuda proposta para se instalar na Galeries Lafayette. Valor Online, 30 mai. 2005. Acesso em: 18 ago. 2007.

FERNANDES, D. Na França, venda cresce 257\% em um ano. Valor Online, 05 set. 2008.

FERNANDES, D. A moda que não sai de moda. Valor Online, 29 out. 2009.

FREITAS, K. R. V. As estratégias empresariais de cooperação e de integração vertical: o caso da indústria de petróleo no Brasil. Monografia de Bacharelado, Instituto de Economia. Rio de Janeiro: UFRJ, 2003.

GIACOMOZZI, A. M.; LABRA, E. S.; CARIDI, S. R. Estrategias Corporativas de Crecimiento de los Grupos Económicos em Chile. Estudios Gerenciales, v. 25, n. 113, oct./dic. 2009, p. 37-53.

GOMELSKY, V. Top Watchmakers Turn Even More Exclusive to Survive. The New York Times Online, 26 nov. 2009.

GREIFFO, T.; TOSCANI, C. V.; BARRETO, N. E. B.; NETO, P. J. S. Mudança ambiental no setor de rochas ornamentais: as empresas no Espírito Santo. In: ENAMPAD, 2006, Salvador. Anais Eletrônicos. Rio de Janeiro: ANPAD, CD-ROM.

GRIFFIN, R. W. Management. Boston: Houghton Mifflin Co., 1996, fifth edition.

GURGEL, F. A. Administração do produto. São Paulo: Atlas, 2001. Segunda edição.

HÄAGEN-DAZS terá mais oito lojas para vender sorvete. Valor Online, 11 abr. 2008. 
HAIR JUNIOR, J. F.; BABIN, B.; MONEY, A. H.; SAMOUEL, P. Fundamentos de métodos de pesquisa em administração. Porto Alegre: Bookman, 2005.

KELLEY, T.; LITTMAN, J. A arte da inovação. São Paulo: Futura, 2002.

KNIJNIK, E., et al. Infrações à ordem econômica. In: MOLL, L. H. (Org.) Agências de regulação do Mercado. Porto Alegre: Editora UFRGS, 2002, p. 129-154.

HERZOG, A. L.; MANO, C. A revanche da indústria. Portal Exame, 22 fev. 2007.

JURGENFELD, V. Marisol prepara expansão da rede Blue Pink. Valor Online, 27 nov. 2008.

KEEGAN, W. J.; GREEN, M. C. Princípios de marketing global. São Paulo: Saraiva, 1999.

KOIKE, B. Varejo fortalece marca própria e preço cai. Valor Online, 13 dez. 2007a.

KOIKE, B. Telhanorte compra lojas da Center Líder em SP. Valor Online, 21 dez. 2007b.

KOIKE, B. Esporte de aventura abastece a indústria. Valor Online, 07 fev. 2008a.

KOIKE, B. Swarovski quer classe média comprando brinco de cristal. Valor Online, 31 mar. 2008b.

KOIKE, B. Doutores da Alegria chega ao varejo. Valor Online, 16 set. 2008c.

KOIKE, B. Com varejo, Prodent dobra receita. Valor Online, 03 mar. 2010.

LAKATOS, E. M.; MARCONI, M. A. Metodologia científica. São Paulo: Atlas, 1991.

LAS CAZAS, A. L. Marketing titânico. São Paulo: Futura, 2001.

LAZZARINI, S. G. Capitalismo de laços. Rio de Janeiro: Campus, 2011.

LENOVO compra alemã Medions para avançar em países desenvolvidos. Folha Online, 01 jun. 2011.

LEVY, M.; WEITZ, B. A. Administração de Varejo. São Paulo: Atlas, 2000.

MACEDO, L. O. B. Perfil de governança e a coordenação de alianças estratégicas do sistema agroindustrial da carne bovina brasileira. Tese (Doutorado em Economia Aplicada). Piracicaba: ESALQ, 2009.

MACHADO, A. Voar é Fashion. Aviação em Revista, abr. 2009, v. 70, n. 698, p. 50-53. 
MADUREIRA, D. Technogym, da Itália, inicia venda ao consumidor final. Valor Online, 20 jul. 2009.

MADUREIRA, D.; KOIKE, B. "Fenômeno" continua a impressionar nas vendas. Valor Online, 13 mar. 2009.

MAGALHÃES, H. Fabricante de celular aposta em degustação. Valor Online, 26 dez. 2006.

MAGALHÃES, H. Nespresso acelera plano de expansão. Valor Online, 12 dez. 2007.

MAGALHÃES, H. Enjoy traz descontração carioca para São Paulo. Valor Online, 08 ago. 2008.

MALTA, C. Nespresso, o negócio de café gourmet da Nestlé, começa a deslanchar. Valor Online, 03 mai. 2007.

MATTAR, F. N. Pesquisa de marketing. São Paulo: Atlas, 2005.

MATTOS, A. Natura abre espaço infantil em shopping. Valor Online, 19 mai. 2011.

MARTIN, A. Smelling an opportunity. The New York Times Online, 08 dez. 2010.

MCCANN, J. E. Doce sucesso. Rio de Janeiro: LTC, 1992.

MICROSOFT vai abrir lojas próprias para enfrentar a Apple. O Estado de São Paulo Online, 13 fev. 2009.

MINADEO, R. Mil perguntas marketing. Rio de Janeiro: Editora Rio, 2005.

MINADEO, R. Alianças no varejo: análise estratégica do caso da criação da Rede Smart pelo Grupo Martins. In: ENEGEP, 28. Rio de Janeiro, 2008a. CD-ROM... Anais

Eletrônicos.

MINADEO, R. Varejo alimentar: uma análise das inovações do Carrefour e Wal-Mart.

ANPAD: XXV Simpósio de Gestão da Inovação Tecnológica. Brasília, 2008b.

MINADEO, R. Alianças no varejo: Análise do Caso Smart à luz do Modelo das cinco Forças de Porter. In: SEMEAD, 2010. São Paulo, USP. CD-ROM... Anais Eletrônicos.

MINADEO, R. Inovações no varejo alimentar: uma análise das estratégias de entrada e de crescimento do Carrefour e Walmart no mercado brasileiro. Revista Brasileira de Inovação, Rio de Janeiro (RJ), 9 (1), p. 119-166, jan./jun. 2010. 
MORAIS, J. lanques, não. Portal Exame, 20 out. 1999. Acesso em: 07 fev. 2009.

MORRIS, C. R. Os magnatas. Porto Alegre: L\&PM, 2005.

MOTTA, R. G.; SILVA, A. V. Aumento da competição no varejo e seu impacto na indústria. Gerenciais. São Paulo: UNINOVE, v. 5, 2006, p. 101-108.

MUITO marketing e cristal novo na prateleira, sempre. Valor Online, 16 out. 2006.

NESPRESSO controls brand with boutiques. Los Angeles Times Online, 09 abr. 2007.

NETO, J. C. S. O processo de internacionalização de empresas sob uma ótica contextualista: um estudo de caso na Cerâmica Portobello S.A. 103f. Dissertação (Mestrado em Administração). UNIVALI - Universidade do Vale do Itajaí. Biguaçu, SC. 2005.

NETO, H. B. A. A Franquia empresarial: nova óptica na revenda de combustíveis. IV Prêmio SEAE de defesa da concorrência. 2009. Disponível em: <http://www.esaf.fazenda.gov.br/esafsite/premios/IVSEAE2009/PDF/2o-Tema1Henrique_B_de_Araujo.pdf>. Acesso em: 31 mai. 2011.

NOBREGA, C. O real triunfo do iPhone. Época Negócios, out. 2009, v. 3, n. 32, p. 68. NOKIA to close Chicago Store. Chicago Tribune Online, 11 dez. 2009.

OLIVAREZ-GILES, N. Nike's retail expansion: 15th California store open and 250 to 300 new stores planned globally. Los Angeles Times Online, 10 nov. 2010.

OPPERMAN, Á. Os riscos de apostar em um só negócio. Época Negócios, v. 2, n. 15, maio/2008, p. 124-125.

PACHECO, P. Usiminas compra fabricante de tubos. O Estado de São Paulo, 19 dez. 2008, Cad. Economia, p. B17.

RÉVILLION, A. S. P. A utilização de pesquisas exploratórias na área de marketing.

ENAMPAD, 2001, 25. Campinas: CD-ROM, Anais Eletrônicos.

RIBEIRO, R. Com operação própria, Harley amplia investimentos no Brasil. Folha Online, 23 mai. 2011.

ROCKOFF, J. D. Pfizer vira farmácia para manter vendas do Lípitor. Wall Street Journal Online, 23 nov. 2011.

RODGERS, B. The IBM Way. São Paulo: Ed. Harbra, 1990. 
ROSA, J. L.; FACCHINI, C. Dell chega ao varejo no Brasil com Wal-Mart. Valor Online, 28 set. 2007.

SAUERBROON, F. F.; FARIA, A. A utilização do método histórico em pesquisa acadêmica de marketing. Florianópolis: Estratégia e Negócios, v. 2, n. 2, jul./dez. 2009, p. 78-95.

SALMON, A. Burning rubber. Forbes Online, 16 jun. 2008.

SALTMARSH, M. A Cup of Coffee, Enriched by Lifestyle. The New York Times Online, 19 fev. 2009.

SAMELLO abre 2a loja na capital federal. Hoje em Dia, Caderno Brasília, n. 733, 21 mai. 2011, p. 13.

SAMSUNG inaugura primeira loja própria. Meio \& Mensagem Online, 06 dez. 2005.

SCARAMUZZO, M. Ipanema Coffees se reestrutura e expande plantio. Valor Online, 01 nov. 2007.

SCHELLER, Fernando. Gigante das commodities agora briga no varejo. O Estado de São Paulo, Cad. Negócios, p. N4, 23 abr. 2012.

SCHWARTZ, A. A.; CARMIEL, O. Apple é a loja que mais vende na Quinta Avenida. Valor Online, 25 ago. 2009

SILVA, E. L. M. Um modelo de rede de lojas da própria indústria: estudo de caso em indústria de revestimentos cerâmicos. Dissertação de Mestrado, 85f. (Engenharia de Produção). Florianópolis: UFSC, 2001.

SILVA, A. L.; BATALHA, M. O. Marketing estratégico aplicado ao agronegócio. In: BATALHA, M. O. (Coord.) Gestão Agroindustrial, Vol. 1. São Paulo: Atlas, 2001, p. 100 161.

SONAGLIO, C. L.; ZAMBERLAN, C. O. Defesa da Concorrência no Brasil: Eficiência Econômica na Análise de Preço Predatório. Porto Alegre: Análise, v. 20, n. 1, jan./jun. 2009, p. 123-137.

SORESCU, A.; FRAMBACH, R. T.; SINGH, J.; RANGASWAMY, A.; BRIDGES, C. Innovations in Retail Business Models. Journal of Retailing, 878 (1, 2011), S3-16.

STERLING, T. Philips third quarter net profit triples to $\$ 256$ million, but sales slump by 11 percent. Chicago Tribune Online, 12 out. 2009. 
STROSS, R. Apple's Lesson for Sony's Stores: Just Connect. The New York Times Online, 27 mai. 2007.

TAUB, E. A. Sony goes to the movies to pitch its brand. The New York Times Online, 23 fev. 2009.

TEIXEIRA, A. A velha dama do novo mercado. Época Negócios, v. 2, n. 22, dez. 2008, p. 130-133.

TUON, F.; MOISÉS, M.; MINADEO, R. ATACAREJO: tendência que veio para ficar ou mero modismo? CONVIBRA, 2011. Disponível em:

<http://www.convibra.com.br/upload/paper/adm/adm_2582.pdf>. Acesso em: 05/12/2011.

URDAN, F. T.; URDAN, A. T. Gestão do composto de marketing. São Paulo: Atlas, 2005.

VALENTI, G. A indústria que virou loja. Valor Online, 05 ago. 2009a.

VALENTI, G. Hering cresce com novas e velhas lojas. Valor Online, 05 ago. 2009b. VAN DEN BROEK, L. Fatores-chave de sucesso na comercialização eletrônica de flores: um estudo multicaso no varejo. 235 f. Mestrado (Enga de Produção). São Carlos: UFSCAR, 2007.

WILSON, C. An american flagship for mauboussin. The New York Times Online, 05 dez. 2008.

WHIGGINS, J. Lindt revê metas e vai fechar 50 lojas nos Estados Unidos. Valor Online, 18 mar. 2009.

WIGGINS, J.; Daneshkhu, S. L'Oréal investe em produto mais barato e estuda ter lojas próprias. Valor Online, 17 fev. 2009.

ZANCUL, E. S. Inovações no modelo de negócios, processos e produtos para atuação em mercados de baixa renda. Porto Alegre: XXV ENEGEP, Anais Eletrônicos. 